\title{
PREDIKSI KELULUSAN MAHASISWA DENGAN JARINGAN SYARAF TIRUAN
}

\author{
Rudy Ansari \\ STMIK Indonesia Banjarmasin \\ e-mail: rudy.ansari@gmail.com
}

\begin{abstract}
ABSTRAK
Kelulusan mahasiswa menjadi salah satu tolak ukur dalam pengambilan kebijakan manajemen perguruan tinggi. Dapat memperkirakan kelulusan mahasiswa setiap tahunnya sangat diperlukan untuk diketahui oleh pihak perguruan tinggi. Dari itu, makalah ini mencoba menerapkan algoritma jaringan syaraf tiruan dalam memprediksi kelulusan mahasiswa, metode yang dipilih untuk digunakan adalah metode backpropagation. Metode ini banyak digunakan peneliti akhir - akhir ini dalam memprediksi suatu masalah. Data sampel dalam penerapan algoritma ini adalah data mahasiswa mulai angkatan 2010 sampai dengan angkatan tahun 2013. Dengan 3 output yaitu lulus terlambat, cepat dan tidak tepat waktu. Dari hasil pembelajaran algoritma yang digunakan, di dapat hasil akurasi yang baik dengan arsitektur yang terbentuk adalah pola 12-9-3.
\end{abstract}

Kata kunci: jaringan syaraf tiruan, backpropagation, akurasi

\begin{abstract}
Graduation became a benchmark in the policy making college management. Can estimate the graduation students annually is needed to be known by the university. Moreover, this paper attempts to apply neural network algorithms in predicting graduation, the selected method to be used is the method of propagation. This method is widely used in the researchers predict a problem. The sample data in the application of this algorithm is data the students began class of 2010 up to 2013. With the third generation output is passed late, fast and timely. From the results of the learning algorithm used obtained good accuracy results with the architecture of the pattern formed is 12-9-3.
\end{abstract}

Keywords: artificial neural network, backpropagation, accuracy

\section{PENDAHULUAN}

Semakin ketatnya persaingan masing-masing perguruan tinggi dalam mencetak mahasiswa yang berkompeten dan berkualitas sehingga menuntut perguruan tinggi tersebut untuk memperbaiki sistem dan kualitasnya menjadi lebih baik lagi, dimana salah satu masalah dalam sistem ialah apabila ada beberapa mahasiswa yang terlambat lulus atau tidak tepat pada waktunya sehingga menjadi kendala untuk kemajuan suatu sistem untuk pengangkatan mutu dan kualitas dari suatu perguruan tinggi tersebut. Apabila suatu sistem dapat memperkirakan atau memprediksi suatu mahasiswa lulus tepat, cepat dan terlambat akan sangat mempermudah suatu sistem yang ada di kampus untuk perancangan bagi mahasiswa tersebut. Jika suatu prediksi dapat akurat untuk suatu akademik dapat digunakan untuk mendapatkan pemahaman tentang resiko faktor dari suatu kurikulum. Pemahaman kesadaran dari para pengajar, pendidikan secara personil dan manajemen akademik sehingga dapat membantu untuk memilih langkah yang tepat dalam segala resiko yang ada dan akhirnya akan menghasilkan penurunan tingkat $d r o p$ out (Dekker, 2009).

Para pembuat kurikulum dapat menggunakan hasil prediksi untuk menyelaraskan perubahan dari kurikulum dan mengevaluasi efek dari perubahan tersebut. Penasehat akademik dapat merujuk ke hasil prediksi ketika memberikan nasehat kepada para mahasiswa yang terdeteksi kemungkinan terlambat lulus sehingga tindakan pencegahan dapat diambil lebih awal. Di samping itu, seorang instruktur atau para pengajar dapat lebih meningkatkan mengajar dan pendekatan pembelajaran, serta intervensi merencanakan dan layanan dukungan bagi mahasiswa (Affendey, Paris, Mustapha, Sulaiman, \& Muda, 2010). Prediksi lama studi dibutuhkan oleh manajemen perguruan tinggi dalam menentukan kebijakan preventif terkait pencegahan dini kasus Drop Out (DO). Prediksi ini bertujuan untuk menentukan faktor akademis yang berpengaruh terhadap masa studi dan membangun model prediksi terbaik dengan teknik data mining (Meinanda, Annisa, Muhandri, \& Suryadi). Akurasi memprediksi mahasiswa berguna di banyak konteks yang berbeda di perguruan tinggi. Sebagai contoh, mengedintifikasi siswa luar biasa untuk beasiswa merupakan bagian penting dari penerimaaan proses sarjana dan pascasarjana lembaga, dan siswa yang lemah mengidentifikasi yang mungkin gagal adalah juga penting untuk mengalokasikan sumber daya les terbatas (Nghe, Janecek, \& Haddawy, 2007).

Dari berbagai penelitian dan jurnal diatas terdapat banyak manfaat bagi akademik atau suatu perguruan tinggi untuk memprediksikan mahasiswa untuk lulus tepat, cepat dan terlambat.

Pemodelan prediktif mengacu pada tugas membangun model untuk variable target sebagai fungsi dari variabel penjelas. dua jenis tugas pemodelan prediktif adalah klasifikasi ,yang digunakan untuk variable kontinyu sasaran. Tujuan tugas adalah untuk mempelajari model yang meminimalkan kesalahan antara nilai prediksi dan benar dari variable sasaran (Affendey, Paris, Mustapha, Sulaiman, \& Muda, 2010).

Artificial Neural Network (ANN) atau jaringan syaraf tiruan sejak diperkenalkan pada sekitar tahun 1940 telah banyak diimplementasikan pada berbagai bidang keilmuan. Jaringan syaraf tiruan banyak digunakan untuk melakukan prediksi atau 
peramalan (Meinanda, Annisa, Muhandri, \& Suryadi). Salah satu algoritma pembelajaran yang cukup akurat adalah dengan algoritma pembelajaran Backpropagation. Sehingga dalam memprediksi kelulusan mahasiswa bisa lebih akurat.

\section{METODE PENELITIAN}

Makalah ini disusun melalui tahapan-tahapan sebagai berikut:

1. Penentuan Masalah Penelitian

Masalah dapat disimpulkan bahwa Algoritma BackPropagation jaringan syaraf tiruan dapat digunakan untuk memprediksi suatu permasalahan yang ada yaitu tentang kelulusan mahasiswa. Sedangkan pertanyaan penelitian adalah: "Bagaimana jaringan syaraf tiruan dengan algoritma pembelajaran Backpropagation lebih akurat dalam menentukan prediksi kelulusan mahasiswa?".

2. Penentuan Pendekatan Komputasi

Pendekatan komputasi yang akan digunakan dalam makalah ini adalah algoritma pembelajaran Backpropagation jaringan syaraf tiruan dimana sampel data dari makalah ini adalah data mahasiswa yang dibagi menjadi data uji angkatan 2010 sampai 2011 dan data testing dari angkatan 2012 sampai 2013.

3. Pengembangan Sistem

Makalah ini akan mengembangkan prediksi kelulusan mahasiswa yang terlambat, tepat, dan cepat.

4. Penerapan Metode

Metode algoritma pembelajaran Backpropagation akan diterapkan untuk prediksi kelulusan mahasiswa..

5. Evaluasi dan Validasi Hasil Penerapan

Evaluasi dilakukan dengan mengamati hasil prediksi. Validasi dilakukan dengan mengukur tingkat akurasi dari prediksi tersebut.

6. Kesimpulan

Menarik kesimpulan dari keseluruhan proses penyusunan dan pengujian hasil prediksi.

\section{A. 2.1 Data Mining}

Istilah data mining memiliki beberapa padanan, seperti knowledge discovery ataupun pattern recognition.Kedua istilah tersebut sebenarnya memiliki ketepatannya masing-masing.Istilah knowledge discovery atau penemuan pengetahuan tepat digunakan karena tujuan utama dari data mining memang untuk mendapatkan pengetahuan yang masih tersembunyi di dalam bongkahan data.Istilah pattern recognition atau pengenalan pola juga tepat untuk digunakan karena pengetahuan yang digali dari dalam bongkahan data yang tengah dihadapi.Bila dalam tulisan ini digunakan istilada data mining, hal ini lebih didasarkan pada lebih populernya istilah tersebut dalam kegiatan penggalian pengetahuan data.Namun demikian, istilah ini memiliki hakikat (notion) sebagai disiplin ilmu yang tujuan utamanya adalah untuk menemukan, menggali, atau menambang pengetahuan dari data atau informasi yang kita miliki.Kegiatan inilah yang menjadi garapan atau perhatian utama dari disiplin ilmu data mining (Susanto \& Suryadi, 2010).

Data mining merupakan analisis dari peninjauan kumpulan data untuk menemukan hubungan yang tidak diduga dan meringkas data dengan cara yang berbeda dengan sebelumnya, yang dapat dipahami dan bermanaat bagi pemilik data. Data mining merupakan bidang dari beberapa bidang keilmuan yang menyatukan teknik dari pembelajaran mesin, mengenal pola, statistik, database, dan visualisasi untuk penanganan permasalahan pengambilan informasi dari database yang besar (Larose D. T.).

\section{B. 2.2 Jaringan Syaraf Tiruan}

Jaringan saraf tiruan adalah model non-linear yang kompleks, dibangun dari komponen yang secara individu berperilaku mirip dengan model regresi. Jaringan syaraf tiruan dapat divisualisasikan sebagai grafik, dan beberapa sub-grafik mungkin ada perilaku yang sama dengan gerbang logika. Meskipun struktur dari jaringan saraf secara eksplisit dirancang terlebih dahulu, pengolahan bahwa jaringan tidak untuk menghasilkan hipotesis (berbagai gerbang logika dan pengolahan lainnya terstruktur dalam jaringan) berkembang selama proses pembelajaran. Hal ini memungkinkan neuron yang membentuk jaringan akan digunakan sebagai pemecahan maslah dari "program itu sendiri" (Cowan, 2013).

\section{2.3 Algoritma pembelajaran Backpropogation}

Dalam backpropagation terdapat beberapa langkah-langkah untuk menyelesaikan masalahnya, dimana ciri dari metode ini adalah meminimalkan error pada output yang dihasilkan oleh jaringan. Backpropagation disebut juga sebagai Multilayer Neural Network sehingga terdri dari beberapa layer yaitu input layer, hidden layer, dan output layer dan pada setiap layer terdapat satu atau lebih artificial neuron (Budhi ST., MT., Gunawan ST., \& Jaowry ST.). 


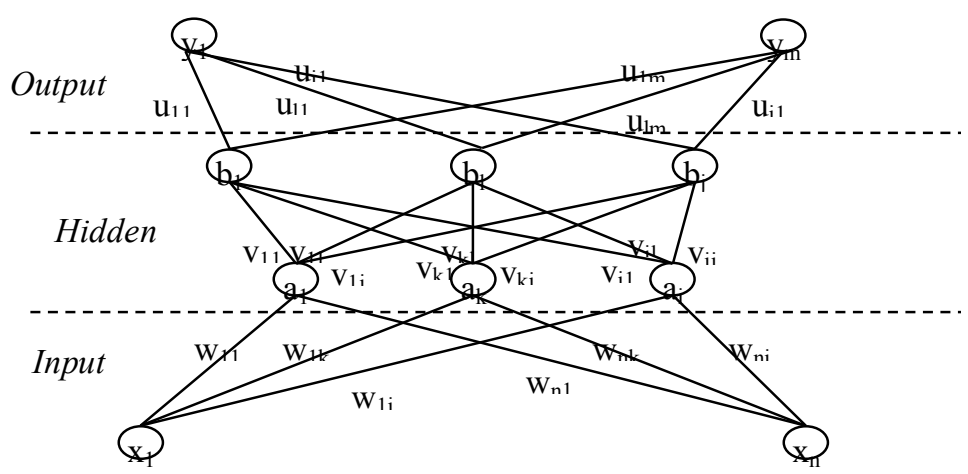

Gambar 1 Arsitektur jaringan syaraf tiruan

Pelatihan dengan metode backpropagation terdiri dari tiga langkah, yaitu:

- Data dimasukkan ke input jaringan (feedforward)

- Perhitungan dan propagasi balik dari error yang bersangkutan

- Pembaharuan (adjustment) bobot dan bias

Secara detail, langkah-langkah pelatihan Backpropagation adalah sebagai berikut:

Langkah 0 : Inisialisasi bobot dan bias

Baik bobot maupun bias dapat diset dengan sembarang angka(acak)dan biasanya angka disekitar 0 dan 1 atau -1(bias positif atau negatif).

Langkah 1 :Jika stopping condition belum dipenuhi, maka langkah 2-9 dijalankan

Langkah 2 :Data training, lakukan langkah 3-8.

Umpan Maju (Feedforward)

Langkah 3 : Tiap unit input (xi, $\mathrm{i}=1, \ldots ., \mathrm{n})$ menerima isyarat masukan xi dan diteruskan ke unit-unit tersembunyi (hidden unit) Langkah 4 : Tiap unit tersembunyi (zj, $\mathrm{z}=1, \ldots, \mathrm{p})$ menjumlahkan bobot sinyal input dan biasnya.

$$
z_{-} i n_{j}=v o_{j}+\sum_{i=1}^{n} x_{i} v_{i j}
$$

$\Rightarrow$ keluaran dari lapisan unit yang tersembunyi menerpakan fungsi aktivasi hitung:

$$
z_{j}=f\left(z_{-} i n_{j}\right)
$$

Langkah 5 : Tiap unit keluaran $(\mathrm{yk}, \mathrm{k}=1, \ldots \ldots, \mathrm{m})$ menjumlahkan isyarat masukan berbobot dengan menerpakan fungsi aktivasi hitung :

$$
\begin{gathered}
y_{-} i n_{k}=w o_{k}+\sum_{j=1}^{p} z_{j} w_{j k} \\
y_{k}=f\left(y_{-} i n_{k}\right)
\end{gathered}
$$

\section{Perambatan Galat Mundur (Backpropagation)}

Langkah 6 : Tiap unit keluaran $(\mathrm{yk}, \mathrm{k}=1, \ldots, \mathrm{m})$ menerima pola pelatihan masukannya. Hitung galat (error) informasinya:

$$
\delta_{k}=\left(t_{k}-y_{k}\right) f^{\prime}\left(y_{-} i n_{k}\right)
$$

Untuk menghitung koreksi bobot:

$$
\Delta w_{j k}=\alpha \delta_{k} z_{j}
$$


dan biasnya:

$$
\Delta w o_{k}=\alpha \delta_{k}
$$

Langkah 7 : Tiap unit tersembunyi $(\mathrm{zj}, \mathrm{z}=1, \ldots, \mathrm{p})$ menjumlahkan delta masukannya (dari unit-unit yang berada pada lapisan atasannya).

Hitung galat (error) informasinya : ${ }_{-} i n_{j}=\sum_{k=1}^{m} \delta_{k} w_{j k}$

$$
\delta_{j}=\delta_{-} i n_{j} f^{\prime}\left(z_{-} i n_{j}\right)
$$

Hitung koreksi bobot

$$
\Delta v_{i j}=\alpha \delta_{j} x_{i}
$$

dan biasnya :

$$
\Delta v o_{j}=\alpha \delta_{j}
$$

Langkah 8 : Tiap unit keluaran $(y k, k=1, . ., m)$ memperbaharui bobot dan bias $(j=0,1, . . p)$

Tiap unit tersembunyi $(z j, z=1, ., p)$ memperbaharui bobot dan biasnya $(i=0,1, . . n)$

$$
\begin{gathered}
w_{j k}(\text { baru })=w_{j k}(\text { lama })+\Delta w_{j k} \\
v_{i j}(\text { baru })=v_{i j}(\text { lama })+\Delta v_{i j}
\end{gathered}
$$

Langkah 9 : Uji syarat berhenti

\section{HASIL DAN PEMBAHASAN}

Data Sampel adalah data mahsiswa STMIK Indonesia Banjarmasin dengan parameter terdiri dari NRP, Nama, Tempat Lahir, Tanggal Lahir, Umur, Pengambilan banyaknya SKS persemester, IPK persemester, rata-rata IPK antara semester 1 sampai dengan semester 4 .

Untuk pengujiannya menggunakan Software data mining yaitu Rapidminer, untuk uji pertama melalui data sample yaitu data angkatan 2006, pada bagian NRP, NAMA, Tempat Lahir dan Tanggal Lahir akan dihilangkan untuk mendapatkan akurasi yang lebih tinggi, pada bagian Lulus atau keterangan untuk lulus ada 3 kategori yaitu cepat, tepat, terlambat dijadikan sebagai label dalam rapidminer sehingga untuk hasilnya menggunakan software rapidminer bisa dilihat pada gambar dibawah:

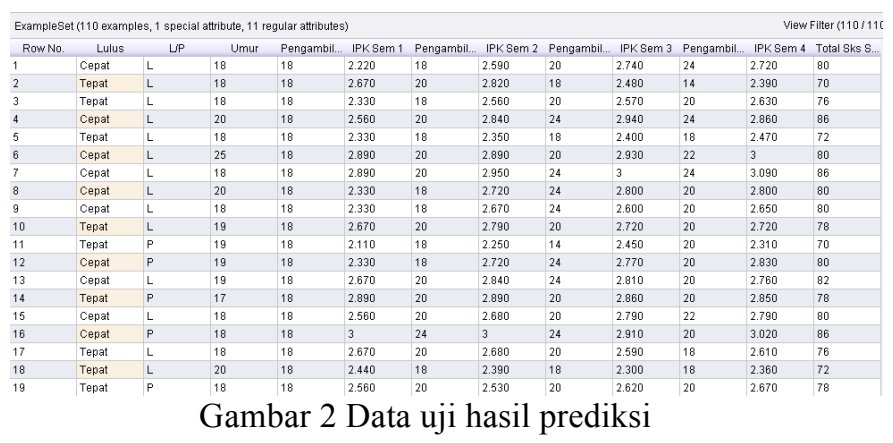




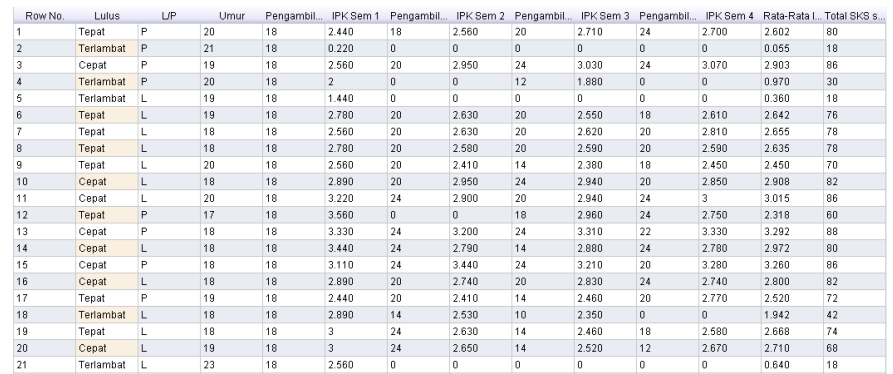

Gambar 3 Data testing hasil prediksi

Dari hasil penerapan algoritma backpropagation jaringan syaraf tiruana didapatkan akurasi prediksi sebesar 92,49\%.

\begin{tabular}{|c|c|c|c|c|}
\hline \multicolumn{5}{|c|}{ 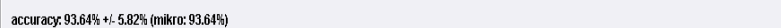 } \\
\hline & true cepat & true Tenat & thue Tellambat & dlass prevision \\
\hline pred. Cepat & 49 & 2 & 0 & $9600 \%$ \\
\hline pred Tepat & 1 & 33 & 3 & $8919 \%$ \\
\hline pred Terlambat & 0 & 1 & 21 & $8545 \%$ \\
\hline class recall & $98.00 \%$ & $91.67 \%$ & $87.50 \%$ & \\
\hline
\end{tabular}

Gambar 4 Hasil akurasi prediksi

Dan arsitektur jaringan yang terbentuk dari hasil pelatihan data tersebut di dapat aristektur jaringan 12-9-3.

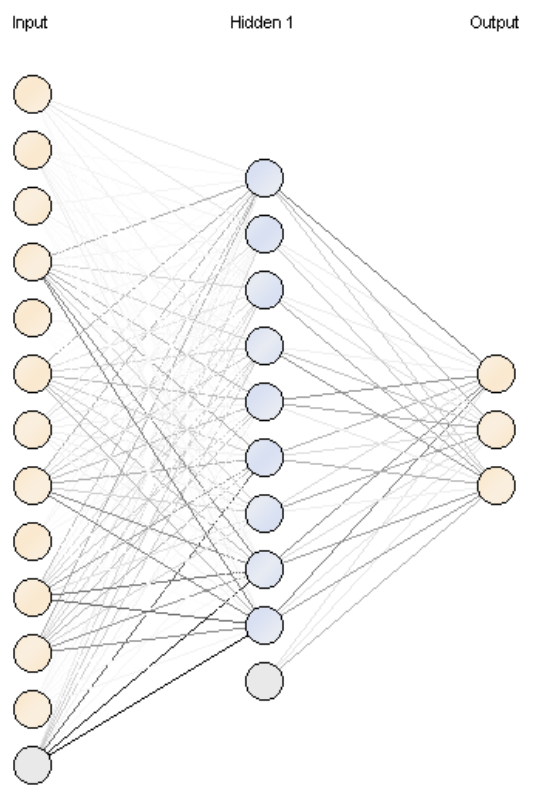

Gambar 5 Hasil arsitektur jaringan syaraf tiruan prediksi kelulusan mahasiswa

\section{KESIMPULAN}

Makalah ini meneliti penggunaan algoritma backpropagation jaringan syaraf tiruan untuk memprediksi kelulusan mahasiswa. Metode jaringan syaraf tiruan menghasilkan akurasi sebesar 92,49\%, dengan input 12, hidden layer 9 dan output 3. Dari hasil tersebut bisa dikatan bahwa metode jaringan syaraf tiruan dapat menghasilkan akurasi cukup tinggi untuk masalah prediksi. 


\section{REFERENSI}

[1] Gerben K. Dekker, "Predicting students drop out: a case study," April 2009.

[2] L.S. Affendey, I.H.M Paris, N. Mustapha, Md. Nasir Sulaiman, and Z. Muda, "Ranking of Influencing Factors in Predicting Students Academic Performance," 2010.

[3] Muhamad Hanief Meinanda, Metri Annisa, Narendi Muhandri, and Kadarsyah Suryadi, "Prediksi Masa Studi Sarjana Dengan Artificial Neural Network".

[4] Nguyen Thai Nghe, Paul Janecek, and Peter Haddawy, "A Comprative Analysis of Techniques for Predicting Academic Performance," 2007.

[5] Sani Susanto and Dedy Suryadi, Pengantar Data Mining : Menggali Pengetahuan Dari Bongkahan Data. Yogyakarta: Andi, 2010.

[6] Daniel T. Larose, Discovering Knowledge in Data.

[7] Mark K Cowan, Machine Learning.: Stanford University, 2013.

[8] Gregorius S. Budhi ST., MT., Ibnu Gunawan ST., and Steven Jaowry ST., "Metode Jaringan Saraf Tiruan Backpropagation untuk Pengenalan Huruf Cetak pada Citra Digital". 